\title{
The Scholarship Horizons in Engineering Technology: Choosing the Best Path
}

\author{
Abi Aghayere, Wiley McKinzie, Warren Hill, David Dvorak, Dale Palmgren, \\ Anthony Brizendine \\ ETC Task Force on ET Scholarship
}

\begin{abstract}
The issue of scholarship in Engineering Technology (ET) is becoming an important topic of discussion within the ET community due to the evolving missions of many institutions that host Engineering Technology programs. Many of these institutions now require some form of documented scholarship from their ET faculty for promotion and tenure purposes, and it is incumbent upon the ET community to support these faculty by defining not only the meaning of scholarship in ET, but also the yardstick by which such scholarship will be assessed. This issue is pertinent to ET because our programs are traditionally of an applied nature with a focus on practice-oriented education. It is therefore logical to expect that ET scholarship should take on an applied flavor and involve our constituencies (students and industry) in meaningful ways.

To define ET scholarship from within the ET community and to develop an appropriate ET faculty workload model, the Engineering Technology Council (ETC) formed a Task Force on ET Scholarship at the ETLI Conference in October 2002 in Norfolk, Virginia. The group was charged to report back to the ETC by June of 2003 at the ASEE Annual Conference in Nashville.

In this paper, the authors will discuss what ET scholarship involves, the importance and relevance of ET scholarship, appropriate Evaluation of ET scholarship, Faculty Workload (teaching, scholarship and service) Model(s), and the Challenges and Opportunities of ET scholarship. A web-based literature survey is carried out to determine the faculty workload policy that currently exists at various colleges and universities across the country, and this information is used in developing the proposed ET faculty workload model presented in this paper.
\end{abstract}

\section{Introduction}

The issue of scholarship in Engineering Technology (ET) is becoming an important topic of discussion within the ET community on the ETD list serve and at conferences as the missions of our institutions evolve. It is no longer acceptable in many institutions to be either teachers or scholars; ET faculty members are now required to be teacher-scholars. ${ }^{3,4,14,16,17,19}$ At these institutions, consulting work is only considered as scholarly or creative activity if the results of the consulting activity lead to publications and presentations ${ }^{14}$; otherwise, it is considered as 
service. Furthermore, information that is disseminated only in course materials and used solely by the faculty member is not considered as scholarship but is merely counted as teaching. ${ }^{14}$ The activity needs to be made public; otherwise, it does not qualify as scholarship or scholarly activity.

Many of these institutions require some form of documented scholarship from their ET faculty for promotion and tenure purposes. ${ }^{8,9}$ However, the meaning of scholarship in ET and the yardstick by which such scholarship is assessed is sometimes vague and unclear at many institutions. This issue is pertinent to ET because our programs are traditionally of an applied nature with a focus on practice-oriented education. It is therefore logical to expect that ET scholarship should take on an applied flavor while maintaining an appropriate objective and thorough peer review component to ensure the quality of ET scholarship and maintain respectability and acceptance within the wider academic community. ${ }^{11,14}$

In a survey of seventy-six institutions with ET programs designed to investigate appropriate creative endeavor, research, and scholarly activities deemed important for promotion and tenure of ET faculty, Buchanan identified the most highly rated creative endeavor activities for promotion and tenure of ET faculty to be: (1) papers or presentations given at technical or instructional conferences, (2) applied research activities, and (3) development of courseware or instructional material. ${ }^{5}$

During an Engineering Technology Council (ETC) Strategy Session at the Annual Conference of the Engineering Technology Leadership Institute (ETLI) in October 2002 at Old Dominion University in Norfolk, Virginia, a Task Force on ET Scholarship was formed. The group was charged with developing definitions of scholarship for engineering technology and developing recommended workload models for engineering technology faculty based on the type of institution. The group, consisting of six ET educators from various institutions must report back to the ETC by June of 2003. This proactive approach to defining ET scholarship is necessary because if we fail to define the parameters of ET scholarship, we risk others outside of the ET community defining it for us. As our institutions evolve, ET must adapt and transform so that ET continues to operate from a position of strength within our various institutions.

This paper addresses the following key issues: 1) What is ET Scholarship; 2) Why should ET faculty pursue scholarship; 3) What resources are available for ET faculty; 4) Appropriate Evaluation of ET Scholarship; 5) How does Scholarship intersect with TAC/ABET Criterion 3 (professional development); 6) Recommended ET Faculty Workload Model, and 7) Challenges to ET Scholarship. 


\section{Survey of ET faculty scholarly activity}

To gauge the current level of scholarly activities among ET faculty, a survey was conducted on the ET listserv. There were a total of fifty e-mail responses to a survey on ET scholarly activity posted on the ETD listserv on November 20, 2002. The respondents were from a total of thirtyeight institutions. Survey responses are summarized in

Table 1 below.

Table 1: Summarized Survey Responses

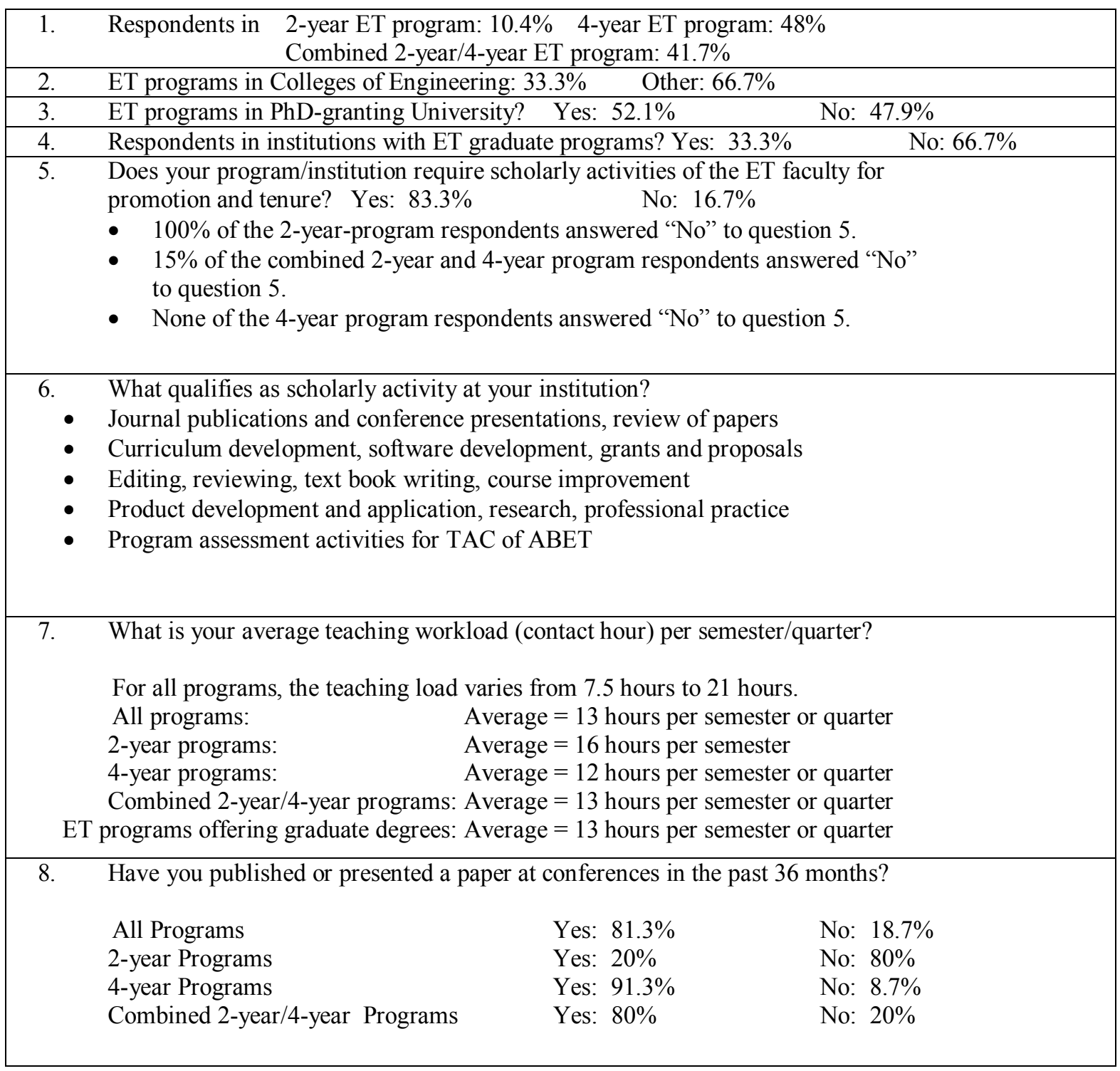

"Proceedings of the 2003 American Society for Engineering Education Annual Conference \& Exposition Copyright (C) 2003, American Society for Engineering Education" 
Table 1 contd: Summarized Survey Responses

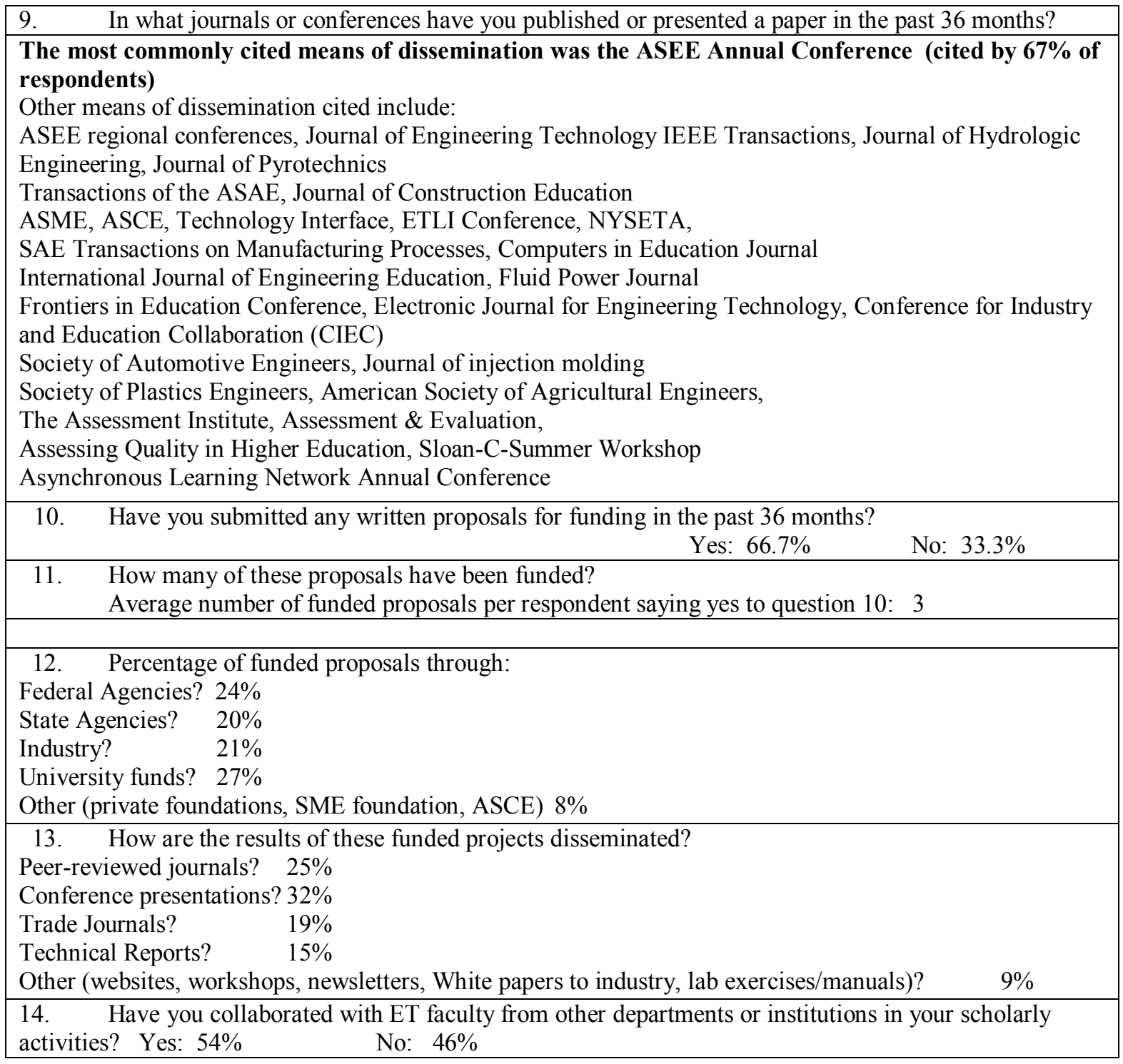

What is ET scholarship?

Many colleges require their faculty to be involved in the triumvirate of teaching, scholarship and service/professional development and some ET programs currently exist in Carnegie Category I research institutions where the ET faculty are required to be involved in scholarly activities for tenure and promotion. ${ }^{5}$ The weight assigned to the various components of the triumvirate varies from institution to institution.

Boyer in his acclaimed 1990 work on scholarship postulated that there are four components of scholarship, namely ${ }^{1,2,7}$ :

"Proceedings of the 2003 American Society for Engineering Education Annual Conference \& Exposition Copyright (C) 2003, American Society for Engineering Education" 
1. Scholarship of discovery

2. Scholarship of integration

3. Scholarship of application

4. Scholarship of teaching

Boyer asserts that these four aspects of scholarship are not mutually exclusive but that they overlap each other.

Brizendine and Brizendine ${ }^{3}$ proposed models and definition for ET scholarship based on a model for Civil Engineering scholarship developed by the ASCE Task Force on Redefining Scholarly Work ${ }^{1}$. In their flexible models, they proposed suggested ranges of percentages for each component of faculty workload. These suggested ranges were selected based upon review of existing models and the authors' collective teaching experiences at various public and private institutions including community colleges, comprehensive baccalaureate and research universities. Recognizing inherent differences in institutions and departmental missions and faculty talents, three flexible models were presented which considered research and/or teaching emphasis based upon Carnegie classification of institutions.

ET programs are different from their engineering counterparts because of the applied flavor and practice-oriented emphasis of our programs. In order to maintain these unique features of ET programs while ensuring recognition for scholarly activities of the ET faculty within the academic community, scholarship in ET has to achieve the following:

- ET scholarship must improve our teaching, add value to the education of our undergraduate/graduate students, and involve our students in meaningful ways.

- ET scholarship must be relevant to industry, and lead to improvement in the curriculum and in undergraduate laboratories

- ET scholarship must be documented and disseminated to others and be open to critical examination by peers outside our department in order to ensure the quality of the scholarly activity and to facilitate continuous improvement in this area of faculty endeavor. ${ }^{9,11}$

Based on this premise, we propose the definition of ET scholarship to include the following:

1. Scholarship of discovery in applied research, leading to the creation of new applications for new and existing technology; patents and licenses.

2. Scholarship of integration, bringing and connecting knowledge together from various sources in the field as in course and curriculum improvements and innovations, developing measures to increase the relevance of ET curriculum to industry, writing of undergraduate text books and book chapters.

3. Scholarship of application through consulting activities, leading to improved processes, practices, programs and products in industry. 
4. Scholarship of teaching in the study of teaching and pedagogical methods based on classroom observations and experimentation, assessment of teaching and learning, and developing strategies for improving student learning. This knowledge is transmitted to students in lectures and to peers in the ET community through presentations at conferences and publication in peer reviewed journals.

Though an ET faculty member may not be able to engage in all four aspects of ET scholarship at any one time, activity that includes a minimum of at least two aspects - one of which will always be teaching - is desirable. The common denominator for all ET scholarly activities should be peer review in some form and the dissemination of the results of those scholarly activities. ET faculty at different points in their career may choose to focus on any of the six possible combination models of ET scholarship listed below:

1. Discovery and Teaching

2. Integration and Teaching

3. Application and Teaching

4. Discovery, Integration \& Teaching

5. Integration, Application \& Teaching

6. Discovery, Integration, Application \& Teaching

The model of ET scholarship above recognizes the creativity and diversity that exist among ET programs and faculty. In fact, Boyer suggested that a bona-fide acknowledgement of the range of faculty talents "would bring renewed vitality to higher learning and the nation."2 It is also noted that combinations \# 2 and 3 appear to fit exceptionally well into the ET paradigm and may represent the preponderance of current ET scholarly activity.

Why should ET faculty pursue scholarship?

The authors conducted a survey of ET faculty on the ETD list serve to gauge the current level of scholarly activity in the ET community. Based on this survey, most institutions already require some form of scholarship of their ET faculty. It is incumbent that ET faculty be fully engaged in scholarly activities, demonstrating our strength and importance as the missions of our institutions evolve. Some reasons why ET faculty must contribute scholarly work include:

1. Scholarly activity re-invigorates the ET faculty and helps him/her improve currency, competency and skills in their field, thus positively impacting student learning. It enables ET faculty to network and to share their experience and expertise in their field or in teaching pedagogy with the ET community; the resulting cross-pollination of ideas is beneficial to the ET community and our students.

2. Scholarly activities involving undergraduate/graduate students stimulate active learning, and develop the creative, critical thinking, and lifelong learning skills in students. It is another opportunity for mentoring our students.

"Proceedings of the 2003 American Society for Engineering Education Annual Conference \& Exposition Copyright (C) 2003, American Society for Engineering Education" 
3. Scholarly activities involving undergraduate students will help them acquire the confidence, public speaking experience, writing and leadership skills that will ensure their future success in the profession.

4. Scholarly activities give the ET faculty an opportunity for their "light to shine" beyond the confines of their offices or classrooms. Publishing and presenting at conferences helps to polish his/her presentation and writing skills while providing professional development through interaction that might not otherwise occur. The results benefit our students and the ET community.

5. Scholarly activities place the ET faculty within our various institutions in a competitive position as the effect of the applied, practice-oriented, and student centered flavor of ET scholarship positively impacts our students.

6. Scholarly activity enhances and promotes the reputation and visibility of our faculty, programs and institutions. It gives ET faculty regional and national recognition, necessary for promotion to full professor at most institutions.

7. Scholarly activity by ET faculty demonstrates academic leadership that is necessary for promotion to full professor at most universities.

8. Scholarly activities provide opportunity for collaboration among ET faculty across disciplines and institutions; this will lead to cross-pollination of ideas that would benefit and strengthen the ET community.

9. Scholarly activities can lead to grants and contracts, patents and new products that ultimately will lead to a) improved quality of life for the general public, b) increased revenue for ET programs, and c) to continuously improving ET curriculum, instruction and facilities.

10. It helps the professional development of ET faculty. Currently, some 20 states require continuing education as a requirement for licensure. ${ }^{20}$ The West Virginia State Board of Registration for Professional Engineers, one of the first states to require continuing professional development of its registered engineers, has awarded 10 professional development hours for each published paper or article on engineering subjects. The New York State Education Department's proposal for the new mandatory 36-contact hour continuing education and professional development requirement for professional engineers awards 10-contact hour credit for one published paper or article, thus underscoring the importance of scholarly activities even in practice. The authors anticipate that many, if not all, other States are sure to follow suit with similar requirements.

11. It provides the ET faculty the opportunity to write textbooks used in the discipline; this promotes ET programs and is beneficial to our students.

"Proceedings of the 2003 American Society for Engineering Education Annual Conference \& Exposition Copyright (C) 2003, American Society for Engineering Education" 
12. It provides the ET faculty an opportunity to advance professional practice in their field or discipline

What resources are available for ET faculty?

Support for ET faculty must come from the interaction of colleagues, industry and the university. Examples of support might include:

1. Mentoring from senior faculty can help those new faculty members understand the university environment. Mentoring may also facilitate introductions of new faculty members with local industry and professional associations.

2. Faculty should also network with discipline specific organizations. Active participation in the operation of the organization should be encouraged. This will also encourage relationships with industry that may lead to professional growth through summer employment and further financial support for applied research.

3. Publishing in recognized professional industrial publications is an excellent way to publish ideas that may attract future support from industry/government. If the publication involves results from a company-supported project, the company may have to approve your paper. This usually is not a problem, as long as there is sufficient lead-time for the paper to travel through the company's approval process.

4. Publishing in the ET/ASEE journals is another good way to disseminate ideas about engineering technology education. In addition, you may have the opportunity to share these ideas with colleagues at international, national and regional conferences via formal presentations.

5. University start-up funds may be available to "seed" a research project. However, the faculty member should identify an industry/government partner for follow-on support.

6. Workload release time is an excellent way to obtain the time required to begin working on research. It effectively is another way to "seed" the faculty member for the purpose of completing enough research to make it more attractive for industry/government support.

\section{Evaluation criteria for ET scholarship}

Boyer asserts that, "the work of the professorate - regardless of the form it takes - must be carefully assessed. Excellence is the yardstick by which all scholarship must be measured. ${ }^{2}$ Effective ways surely must be found to evaluate faculty performance in the four dimensions of scholarship we discuss in this report, as difficult as the process may be. Faculty who engage in research, in teaching, in service, or in investigative work must demonstrate to the satisfaction of peers that high performance standards have been met." 
In evaluating the scholarship of application, a written record of the project such as a technical report and/or a patent and an evaluation by those who received the service are necessary ingredients for evaluating this type of scholarship. Since most of the work done may have taken place off campus, outside experts could be asked to sit on the committee reviewing the scholarly activity. Questions to be asked when evaluating the scholarship of application include:

"Is the activity directly or indirectly related to the academic field or expertise of the professor?" "Have project goals been defined, procedures well planned, and actions carefully recorded?" "In what ways has the work not only benefited the recipient of such activity, but also added to the professors' own understanding of his or her academic field?"

In evaluating the scholarship of integration, Boyer asserts that a broader range of writing beyond refereed journals and scholarly books be considered, such as writing of textbooks, trade journals, and writing for non-specialists or nonacademic publications, developing quality computer software, designing new courses, and curricular innovations. Questions to be asked in assessing this type of scholarship include:

"Does the work show a careful understanding of discipline?"

"Have key issues been well defined and creative insights well presented?"

"Has the essential message been clarified?"

"In what ways has the public discourse been advanced?"

"Have course objectives been well defined?"

"Has the relevant literature been cited and integrated in the course?"

"Are key points covered and appropriate thematic relationships made?"

The scholarship of discovery is usually assessed by refereed journal publications and conference presentation, and/or changes in industry practice that result from the applied research.

The scholarship of teaching goes beyond the act of teaching; it arises from a reflection on the act of teaching and thus should inform and improve the act of teaching. In evaluating the scholarship of teaching, peer reviewed articles about teaching techniques - what works and what doesn't and strategies for improving student learning and pedagogy- published in journals or presented at conferences should be used as the means of assessment.

The relative weights applied to the four components of ET scholarship defined earlier will vary from institution to institution and even among various disciplines. In order to evaluate the various aspects of ET scholarship, the following list of evidence of scholarship is proposed. $^{10,11,14}$

1. Publication of articles in peer-reviewed journals or conferences. Examples of acceptable venues, in addition to traditional disciplinary journals and annual and specialty conferences, include the Journal of Engineering Technology (JET), Technology Interface (an ET online journal), refereed annual conference proceeding of ASEE, ASEE regional conferences, Journal of College Teaching. These articles may be in the discipline of the

"Proceedings of the 2003 American Society for Engineering Education Annual Conference \& Exposition Copyright (C) 2003, American Society for Engineering Education" 
ET faculty member or of a pedagogical nature.

2. Invited presentation of non-refereed papers and reports to peers at professional or technical meetings.

3. Demonstrated application of the scholarship in the field or discipline resulting in changes in industry practice; this could be documented in a technical or design report.

4. Grants for applied research, curriculum development, or undergraduate laboratory expansion or funded projects and consulting work that results in technical reports, peer reviewed papers and presentations at conferences.

5. Patents and licenses or new computer software, or publishing a textbook or laboratory manual in the field or discipline.

6. Incorporation of the results of the scholarly activity into courses and/or programs

7. Honors or awards for scholarly activities

8. Development of new courses and new lab experiments, curriculum revision, and dissemination of this information to the ET community.

9. Articles on consulting work, describing non-proprietary information on the work carried out, basic problem addressed and proposed solutions

\section{ET faculty workload model}

A web-based literature survey of faculty workload policies at various institutions across the country was completed. The institutions varied from Community Colleges to Carnegie Category I research institutions. The following conclusions can be drawn from the available information:

A traditional 40-40-20 distribution between teaching, scholarship and service is widely used at Carnegie Category I Research and Doctoral I institutions. At Baccalaureate institutions, 60-20-20 or 70-20-10 distributions between teaching, scholarship and service is more common with a target goal of $15 \%$ of faculty time allotted for scholarship at many Baccalaureate institutions.

Community College faculty have a typical workload of 15 to 20 or more contact hours per week. The faculty in Baccalaureate institutions have a typical workload of 12 to 15 contact hours per week, with 12 hours being most common. The faculty in Carnegie Doctoral I institutions and Comprehensive (i.e. offering Master's degrees) institutions have a typical workload of 8 to 10 contact hours per week. The faculty in Carnegie Category I Research institutions have a typical workload of 6 to 8 contact hours per week. 
To account for the time spent by faculty on lecture preparation, grading and office hours, a multiplier of the faculty teaching contact hours is typically used. ${ }^{8,12,13,17}$ The multiplier for faculty contact hours that allows for lecture preparation, lectures, grading and office hours varies from 2.0 for existing courses or laboratory sections to 3.0 for new courses. The Tennessee Board of Regents regulations assume that teaching one 3-credit course should consume approximately twenty percent of a faculty member's work week ${ }^{16}$; this translates to a contact hour multiplier of 2.67 assuming a 40-hour work-week. At the University of North Texas, a 3-credit hour class is assumed to be equivalent to $16.7 \%$ of faculty total weekly workload, which translates to a contact hour multiplier of $2.23 .{ }^{18}$ An average multiplier of 2.5 has been adopted in this paper for developing the proposed ET faculty workload model.

The Bureau of Labor Statistics in 1997 reported that the average workweek for college and university professors is 45 hours. In this paper, we have adopted a full-time workload of 40 hours per week for developing the proposed ET faculty workload model.

Using a 40-hour work week as our benchmark and assuming a multiplier of 2.5 per contact hour to account for lecture preparation, teaching of lectures, grading and office hours, a faculty workload model is proposed as shown in Table 2 . 


\begin{tabular}{|c|c|c|c|c|}
\hline \multicolumn{2}{|r|}{ Table 2: } & \multicolumn{2}{|c|}{ Faculty Workload Model } & \multirow[b]{2}{*}{$\begin{array}{l}\text { Total hours of } \\
\text { work per } \\
\text { week }\end{array}$} \\
\hline $\begin{array}{c}\text { Teaching } \\
\text { Contact hours } \\
\text { per week }\end{array}$ & $\begin{array}{l}\text { Actual Time } \\
\text { Spent on } \\
\text { Lecture Prep, } \\
\text { Lecture, and } \\
\text { Office hours } \\
(2.5 \mathrm{x} \\
\text { teaching } \\
\text { contact hours) }\end{array}$ & $\begin{array}{c}\text { Hours per } \\
\text { week spent on } \\
\text { Scholarly } \\
\text { activities }\end{array}$ & $\begin{array}{c}\text { Hours spent } \\
\text { per week on } \\
\text { Service } \\
\text { activities }\end{array}$ & \\
\hline 6 & $15(37.5 \%)$ & $15(37.5 \%)$ & $10(25 \%)$ & 40 \\
\hline 8 & $20(50 \%)$ & $15(37.5 \%)$ & $5(12.5 \%)$ & 40 \\
\hline 9 & $22.5(56.25 \%)$ & $12.5(31.25 \%)$ & $5(12.5 \%)$ & 40 \\
\hline 10 & $25(62.5 \%)$ & $10(25 \%)$ & $5(12.5 \%)$ & 40 \\
\hline 12 & $30(75 \%)$ & $6(15 \%)$ & $4(10 \%)$ & 40 \\
\hline 13 & $32.5(81.25 \%)$ & $4.5(11.25 \%)$ & $3(7.5 \%)$ & 40 \\
\hline 14 & $35(87.5 \%)$ & $3(7.5 \%)$ & $2(5 \%)$ & 40 \\
\hline 15 & $37.5(93.8 \%)$ & $1.5(3.75)$ & $1(2.5 \%)$ & 40 \\
\hline 16 & $40(100 \%)$ & 0 & 0 & 40 \\
\hline 18 & $45(100 \%)$ & 0 & 0 & 45 \\
\hline 20 & $50(100 \%)$ & 0 & 0 & $\overline{50}$ \\
\hline 22 & $55(100 \%)$ & 0 & 0 & 55 \\
\hline
\end{tabular}

A graphical representation of the proposed model is shown in Figure 1.

From the proposed model, it is obvious that institutions that have the triumvirate mission of teaching, scholarship and service must appropriately balance teaching load of their ET faculty if they are to succeed in engaging in scholarly endeavors. Institutions with teaching as their main focus and where the faculty teaching commitment exceeds 16 or more hours, such as Community Colleges, cannot expect much scholarly activities from their ET faculty without some reduction in their current workloads. In order to maintain a vital scholarship program when faculty member's teaching commitment reaches 14 hours, the faculty member's teaching and scholarship must be almost completely integrated (combination \#2 of the scholarship model), and will probably involve collaboration with other faculty at the institution. It is our hope that ET programs and faculty will use the graphical workload model in Figure 1 to determine the optimum combination of teaching, scholarship and service that fits the mission of their institutions. The relative weights assigned to the trio of teaching, scholarship and service will vary depending on the mission of the institution. 
Figure 1: $\quad$ ET Faculty Workload Model

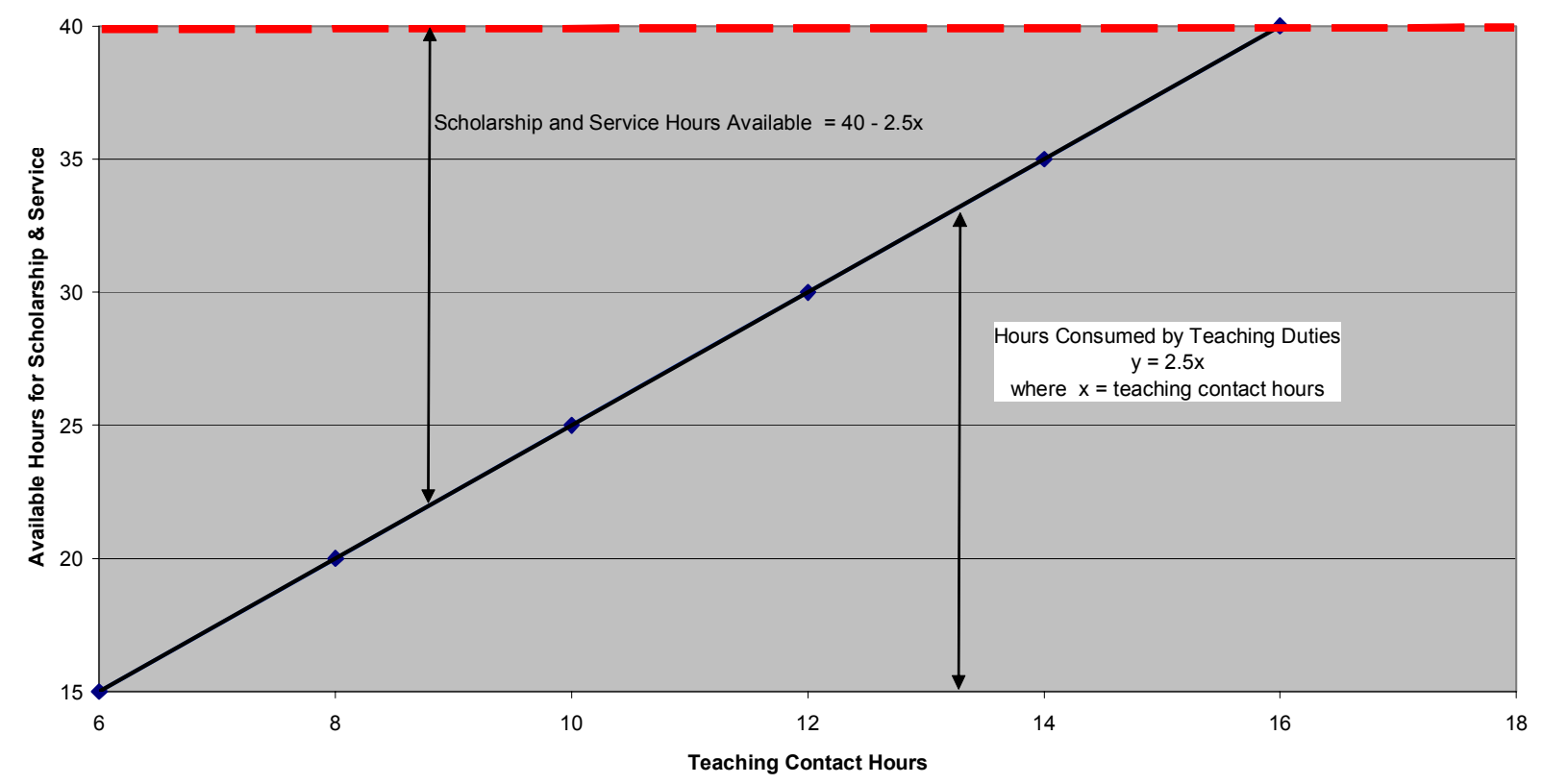

\section{Challenges to scholarship in ET}

There are several challenges facing ET faculty who wish to engage in scholarly activities; these include:

1. How and where to obtain funding for projects. Available funding agencies include Federal Government Agencies such as NSF, State Government Agencies, private Foundations, and industry.

2. The limited number of journals and conferences where ET faculty can publish and present the results of their scholarly activity. This may be overcome by considering a broader range of venues where ET faculty scholarly work can be published, such as web publishing

3. How do we involve our undergraduate students in scholarly activities and yet maintain the practice-oriented and hands-on approach that is the hallmark of ET programs.

4. Some consulting work requires a non-disclosure agreement that would prevent the ET professor from publishing any information regarding that consulting activity.

5. How will ET faculty in institutions that do not have adequate experimental research laboratories and research infrastructure obtain the funding and space required to set up such labs? 
6. How do ET faculty who already have full teaching loads incorporate scholarly activities into their already overloaded schedule? Are institutions with ET programs willing to reduce the teaching load of ET faculty to enable them to have sufficient time for scholarly activities?

7. Are institutions prepared and willing to help ET faculty who have traditionally done only teaching, by providing the funds for them to upgrade their research and writing skills?

8. To whom will patent and licensing rights belong if new applications are developed as a result of ET scholarship?

9. How does the ET community facilitate collaboration on scholarly activities across disciplines and institutions in order to leverage the strengths of various ET faculty and programs?

\section{Conclusions}

The authors have presented a definition of ET scholarship and developed an appropriate ET faculty workload model that includes teaching, scholarship and service. Although scholarship may be expressed in different forms, ET faculty scholarship must lead to improvement in teaching quality, enhancement of active student learning, and benefit the community through dissemination of the results of that scholarship.

As institutions with ET programs evolve, it is incumbent upon the ET faculty to be proactive, and not reactive, in defining ET scholarship at their institutions to ensure that they are recognized for their considerable and meaningful contributions to the academy, their disciplines, the public, and other constituents. Without that recognition, the ET faculty cannot be in positions of strength and influence in their institutions. They must lead the efforts to develop a scholarship culture in ET that meet the needs of our constituents - students and industry - while earning the esteem of our colleagues in the academy. The definition of ET scholarship and the faculty work load model proposed in this paper can be used by ET faculty as guidelines for their input into the discussions on scholarship at their respective institutions.

Faculty with experience in scholarly activities should be encouraged and provided incentives to act as mentors for other faculty with lesser experience including co-authoring papers and proposals. ${ }^{4}$ Collaboration on scholarship among ET faculty across disciplines and between institutions should be encouraged and facilitated by the ETC to help build a scholarship culture in ET. The ETC should work on increasing the bandwidth for publishing through creating more ET journals and more online journals.

Institutions with ET programs should provide the necessary resources of space, time and money to encourage ET faculty to engage in scholarship. ET programs should provide tangible rewards for their faculty who are currently engaged in scholarship. This will motivate other ET faculty to engage in scholarship in addition to their teaching responsibilities.

"Proceedings of the 2003 American Society for Engineering Education Annual Conference \& Exposition Copyright (C) 2003, American Society for Engineering Education"' 
It is the collective belief of the authors that ET faculty and programs will continue to thrive and prosper, and adapt to change and engage in scholarship that serves and benefits our various constituencies, thereby continuously improving their stature, importance and respectability within the academic community

Bibliography

1. Al-Khafaji, A; Clemence, S; Drnevich, V.P.; Kupferman, M; Lenox, T.A.; Marcusson III., W.F.; Mitchel, G; Yao, J.T.P. (1998). The Scholarship Landscape in Civil Engineering: A Bridge between Rhetoric and Reality. American Society of Civil Engineers, NY

2. Boyer, Ernest L. (1990). Scholarship Reconsidered: Priorities of the Professoriate. Princeton, NJ: Carnegie Foundation for the Advancement of Teaching.

3. Brizendine, Anthony L; Brizendine, Laora D, Redefining Scholarship: A Win-Win Proposition for Engineering \& Technology, ASEE Annual Conference, 1999.

4. Buchanan, W.W., Expectations for Faculty Development in Engineering Technology, ASEE Annual Conference, 1997.

5. Buchanan, W.W., Survey of Creative Criteria for Promotion and Tenure of Engineering Technology Faculty, Journal of Engineering Technology, 13(1), pp. 30-36, 1996.

6. Civil Engineering Technology, Environmental Management \& Safety Department, RIT, Promotion Criteria and Guidelines, December 2001.

7. Felder, R.M., The Myth of The Superhuman Professor, Journal of Engineering Education, Vol. 82, No 2, pp. 105-110, 1994.

8. Hill, Warren R., Faculty Workload, ASEE Annual Conference, 2000.

9. Hochstein Deborah, Merging Research with Service and Teaching in an Engineering Technology Department, ASEE Annual Conference, 1997.

10. Hyman, D; Gurgevich, E; Alter, T. UniSCOPE 2000: A multi-dimensional model of scholarship for the $21^{\text {st }}$ century", $9^{\text {th }}$ Annual AAHE Conference on Faculty Roles \& Rewards, Tampa, FL, Feb 1-4, 2001.

11. Lozano-Nieto Albert, Integrating Teaching, Research and Service to Develop Scholarly Publications, ASEE Annual Conference, 2002.

12. Milwaukee School of Engineering Web site, Faculty Load Calculation, http://www/msoe.edu/eecs/ce/ceb/barnicks/courses/cs489/req0.htm

13. Parks, D.J; Gabert, M.C.; Affleck, S.B; and Kuhr, H.J, Quantifying Academic Faculty Load, ASEE Annual Conference, 1998.

14. School of Technology, College of Engineering and Technology, Brigham Young University, Provo, Utah, Research, Scholarship, and Creative Activity, 15 pp., Frontiers in Engineering Technology Scholarship Conference, University of Houston, Houston, October 2002.

15. Simone, A.J., Teaching, Scholarship, and Service at RIT: Expectations and Enablers, Presentation to Faculty Assembly, 5 pp., April 15, 2002.

16. Statement Regarding Faculty Scholarship, University of Northern Colorado, http://asweb.unco.edu/Evaluation/fac_eval_9.htm

17. Thompson, J.J., A Juggling Act, ASEE Prism, pp. 31-32, Feb 2000.

18. University of North Texas Policy Manual: Academic Workload, http://www.unt.edu/planning/UNT_Policy/volume3/15_1_9.html

19. Verma, Alok K., Meeting Research and Publication Requirements in an Undergraduate ET Program Through Senior Design Projects, ASEE Annual Conference, 2001

20. Goupil, Jennifer, Examining Professional Licensure, Structural Engineer, pp. 30 - 35, February 2003

"Proceedings of the 2003 American Society for Engineering Education Annual Conference \& Exposition Copyright (C 2003, American Society for Engineering Education" 
ABI AGHAYERE is Associate Professor of Civil Engineering Technology at the Rochester Institute of Technology, Rochester, New York.

WILEY MCKINZIE is Dean of College of Applied Science and Technology at the Rochester Institute of Technology, Rochester, New York.

WARREN HILL is Dean of the College of Applied Science and Technology at Weber State University, Ogden, Utah

DAVID DVORAK is Director of the School of Technology at the University of Maine, Orono, Maine.

DALE PALMGREN is Assistant Dean of the College of Technology and Applied Sciences at Arizona State University-East, Mesa, Arizona

ANTHONY BRIZENDINE is Chair of the Department of Engineering Technology in the William States Lee College of Engineering at The University of North Carolina at Charlotte. 